\title{
A MUSLIM AND CHRISTIAN ORIENTATION TO HUMAN RIGHTS: HUMAN DIGNITY AND SOLIDARITY
}

\author{
David L. Johnston ${ }^{*}$
}

On the far side of the terrifying abyss of World War II-the culmination of humanity's most horrific and deadly half century-nations came together and hammered out the text of the Universal Declaration of Human Rights. As any legal (or quasi-legal) ${ }^{1}$ document of its kind, it truly was the product of an arduous process of negotiation and debate- two years, in fact. Of the forty-eight original signatory nations, none voted against it and only eight abstained, mostly communist bloc countries and one Muslim-majority State, Saudi Arabia. ${ }^{2}$ As the Muslim world witnessed a resurgence of conservative religiosity starting in the 1970s, more criticism of the human rights concept and its international law documents arose in that context. ${ }^{3}$ As a result, European Muslims drafted the "Universal Islamic Declaration of Human Rights" in 1981 and nine years later the Organization of the Islamic Conference (OIC) published the Cairo Declaration of Human Rights in Islam. ${ }^{4}$

My purpose in this paper is not to discuss the intra-Muslim debates

* David L. Johnston served as a pastor and teacher in Algeria, Egypt, and the West Bank for sixteen years. He later obtained a PhD in Theology and Islamic Studies from Fuller Theological Seminary. He then spent five years as postdoctoral research associate at Yale University. He has been connected to the University of Pennsylvania as a Visiting Scholar since 2006 and has taught as an adjunct lecturer both there and at St. Joseph's University in Philadelphia. His research focuses on the intersection of Islamic Law and Theology and on Muslim-Christian dialogue. His Articles and essays have appeared in Islamochristiana, Islamic Law and Society, Die Welt des Islams, The Maghreb Review and Comparative Islamic Studies. He is the author of two books: Evolving Muslim Theologies of Justice: Jamal al-Banna, Mohammad Hashim Kamali, and Khaled Abou El Fadl (Penang, Malaysia: Universiti Sains Malaysia, 2010), and Earth, Empire and Sacred Text: Muslims and Christians as Trustees of Creation (London: Equinox, 2010, paperback in 2013). He blogs on his own website, www.humantrustees.org.

1. Eleanor Roosevelt chaired the 18-member Commission of Human Rights which drafted the "Declaration" - a wise decision in retrospect, for it left all the more binding legal issues to be resolved within the two following "covenants:" International Covenant on Civil and Political Rights (ICCPR), Dec. 16, 1966, G.A. Res. 2200A (XXI), 21 U.N. GAOR Supp. (No. 16), and the International Covenant on Economic, Social, and Cultural Rights (ICESCR), Dec. 16, 1966, G.A. Res. 2200A (XXI), 21 U.N. GAOR Supp. (No. 16).

2. YeARBOOK OF THE UNITED NATIONS 535 (last visited Oct. 11, 2014, archived at http://perma.cc/WVY6-3RBV). That said, it is notable that the following countries did sign it: Afghanistan, Egypt, Iran, Iraq, Lebanon, Pakistan and Turkey. Id.

3. See generally Ann ElizABEth MAYER, IsLAm AND Human Rights: Tradition AND Politics (2012) and NisRine Abiad, Sharia, Muslim States ANd InTERnAtional Human Rights TREATy OBLigations (2008).

4. MAYER, supra, at 30-32. 
that are still ongoing relative to these issues, ${ }^{5}$ but rather to argue from a comparative perspective that human rights discourse is reinforced by the central tenets of both Islam and Christianity in two areas: its universality and its application to the economic sphere. The core of the human rights paradigm is that all human beings, by virtue of simply being human, are bearers of inalienable rights. The intrinsic dignity of the human person, moreover, is the guarantee of the universality of the international human rights standard. Yet this is not by any means an uncontested statement. Arizona State University law professor Fernando Tesòn recognizes the challenge coming from some legal scholars, anthropologists and philosophers in the form of "cultural relativism:"

We are witnessing an unequivocal process of universalization of the concern for human dignity. As international law becomes more responsive to the demands for individual freedom, however, it necessarily challenges the validity of certain state practices reflecting geographical and cultural particularities. The tension between national sovereignty and the enforcement of international human rights standards is highlighted when governments point to national cultural traditions to justify failures to comply with international law. ${ }^{6}$

I will come back to Tesòn's argument, but first, I present some foundational theological tenets in both Islam and Christianity that sustain and unequivocally affirm the universal dignity of the human person, both male and female.

\section{THE CREATION PRIVILEGE AND MANDATE OF HUMANITY}

My own research has shown that Islam, Judaism, and Christianity share a similar view of Adam's empowerment by God at creation as his trustee, steward, or deputy on earth. ${ }^{7}$ Both the Qur'an and Bible further teach that this mandate relates to the entire human race through Adam, its first and representative member. Here is the key verse in the Qur'an, keeping in mind that there are several verses where this term khalifa for

5. See generally David L. Johnston, Maqasid al-Shari'a: Epistemology and Hermeneutics of Muslim Theologies of Human Rights, 47 DiE WeLt DES IsLAMS 149, 149-87 (2007) (theology and law are intermingled, as I argued there and will continue to do so here).

6. Fernando R. Teson, International Human Rights and Cultural Relativism, in THE Philosophy of Human Rights: Readings in Context (Paragon Issues in Philosophy) 379-396 (Patrick Hayden ed. 2001).

7. See David L. Johnston, Earth, Empire and Sacred TeXt: Muslims and Christians as TRUstees of CREATION ch. 3 (2013). 
"vicegerent" (or "trustee," etc.) appears in its plural form:

Behold, thy Lord said to the angels: "I will create a vicegerent on earth" They said: "Wilt Thou place therein one who will make mischief therein and shed blood? Whilst we do celebrate Thy praises and glorify Thy holy (name)?" He said: "I know what ye know not."

This initial declaration of humankind's mandate to represent God on earth and thereby be held accountable for the way humans acquit themselves of this responsibility is also an affirmation of their inherent worth in God's eyes - all without exception, by virtue of their creation. This fact is reinforced by two other concepts in the Qur'an. The very next verse explains, at least in part, the reason for humanity's empowerment: "And $\mathrm{He}$ taught Adam the nature of all things; then He placed them before the angels, and said: "Tell me the nature of these if ye are right." "9 This was a challenge to the angels, who initially only saw bloodshed and mayhem in the creation of this new species. ${ }^{10}$ Naturally, they could not respond to God's challenge, since literally "knowing the names of all things" was not an ability with which they were endowed. When Adam in turn had demonstrated his Godgiven capacity for reason and the discernment between good and evil (the modern consensus on this verse), the angels bowed down to Adam in humble admiration and recognition of God's wisdom. ${ }^{11}$

The other concept is that of God's giving humanity the "trust" of the earth's management: "We did indeed offer the Trust to the Heavens and the Earth and the Mountains: but they refused to undertake it, being afraid thereof: but man undertook it - he was indeed unjust and foolish." ${ }^{\prime 2}$ A cursory reading of this verse will not yield, admittedly, the sense of humanity's trusteeship of the earth. I have delved extensively into how this verse is tied to the above verse on Adam's trusteeship in contemporary Islamic thought elsewhere. ${ }^{13}$

A similar picture of humanity's highest role in creation and mission to rule the earth in God's stead is found in the Bible's first page, Genesis 1; here the mandate is "be fruitful and multiply" and "fill the earth and govern it." 14 It is preceded by a short poem inspired by the Ancient Near-Eastern

8. Abdullah Yusuf Ali, The Holy Qur’an: Text, Translation and Commentary 2:30 (1987) (hereinafter Qur'an).

9. Id. at 2:31.

10. Id. at $2: 31 a$.

11. Id. at $2: 34 b$.

12. Id. at 33:72; another verse is often quoted, "We have honored the children of Adam; provided them with transport on land and sea; given them for sustenance things good and pure; and conferred on them special favors, above a great part of Our creation." Id. at 17:70.

13. See Johnston, supra note 7.

14. Tyndale House Publishers, Inc., Holy Bible: New Living Translation 1:28 
concept of the king as God's image on earth:

"So God created human beings in his own image.

In the image of God he created them;

male and female he created them." 15

So in both cases - in the Qur'an and the Bible- human beings are brought into being at the apex of creation and given the responsibility to rule over all the rest with great care, wisdom, and justice.

This declaration of intrinsic human dignity is only a theological statement - necessary, no doubt, but certainly not sufficient. In the case of the Muslim understanding of religion, orthopraxy (right action) trumps orthodoxy (right doctrine). ${ }^{16}$ Plainly an oversimplification, this adage nonetheless points to the fact that for Muslims, as well as for Jews, God's revelation is more about law than theology. Shari'a is thus God's blueprint helping people to find the "straight path" that will lead to life in this world and the next. ${ }^{17}$

The Islamic emphasis on law would then lead us to inquire about how classical Islamic Shari'a protected the rights of minorities under Muslim rule or whether men and women were given the same rights in the medieval or late medieval period. But that would be an anachronism, as Europe, for instance, as late as the seventeenth century, was plunged in fratricidal wars of religion-hardly a model of "religious freedom." ${ }^{18}$ In the many centuries before that, as well, European states, starting with the Holy Roman Empire, were famous for discriminating against and at times massacring those whose beliefs did not match those of the ruling elites, and the Jews in particular. ${ }^{19}$

In 2006, Rowan Williams, then Archbishop of Canterbury, convened the fifth annual "Building Bridges" seminar of Christian and Muslim scholars at Georgetown University, Washington, D.C.; the proceedings were published in a volume Michael Ipgrave edited: Justice and Rights: Christian and Muslim Perspectives. ${ }^{20}$ Two chapters amply illustrate my

(2nd ed. 2004).

15. Id. at 1:27.

16. John L. Esposito, Islam: the Straight Path 85 (4th ed. 2011).

17. See generally id.

18. See, e.g. Thirty Years' War, HISTORY, http://www.history.com/topics/thirty-yearswar (last visited Oct. 11, 2014, archived at http://perma.cc/N7CY-HAZ3); see also English Civil Wars, HistoRY, http://www.history.com/topics/british-history/english-civil-wars (last visited Oct. 11, 2014, archived at http://perma.cc/A9ZX-BJC9).

19. See generally Mark R. Cohen, Under Crescent and Cross: The Jews in the Middle Ages (2008) (a comparative study of Jews in the medieval period under European Christendom and under Muslim rule, showing that the Jews were much better off in Muslim lands).

20. Justice and Rights: Christian and Muslim Perspectives (Michael Ipgrave ed. 2009). 
above point. In the first, Emory University professor Vincent J. Cornell, representing the Muslim side, demonstrates from the events surrounding the mid-tenth-century capture of Baghdad by the Turkish Seljuk army loyal to the Shi'ite dynasty in Egypt (the Fatimids) that "theology and law both matter in Islam and that theological issues cannot be artificially separated from legal and political conflicts." 21 Not surprisingly, as various Muslim sects, ethnicities, and dynasties were often warring with one another and "excommunicating" one another, they were also inclined to treat nonMuslim minorities as less than human-despite Shari'a norms of relative tolerance, at least for "the people of the book." ${ }^{22}$ In the next chapter, John Langan, on the Christian side, demonstrates the extreme attraction an authoritarian regime representing one religious sect had on Christian realms up until the Thirty Year War. ${ }^{23}$ In the final analysis, neither Muslims nor Christians seemed to know much about, or cared to practice anything closely resembling what we understand today as human rights policies.

As mentioned above, the human rights concept, as a tool of international law, was hammered out laboriously by nations shaken to the core by two world wars. Though there are potential theological building blocks in the Christian and Muslim traditions, international law is a quintessentially modern idea born in the midst of very specific geopolitical and intellectual conditions. As I have argued elsewhere, theology is a reflection on sacred texts based on a particular religious tradition and in light of a specific sociocultural context. ${ }^{24}$ True, Muslims have a long history of legal norms that range in application from the individual to the family, and commercial relations to economic and political realities. ${ }^{25}$ Yet those bodies of jurisprudential rules $(f i q h)^{26}$ spread out between six rather diverse schools of law, were mostly crystallized - at least in their philosophy of law and cultural outlook - somewhere around the eleventh century. ${ }^{27}$ Most

21. Vincent J. Cornell, Religious Orthodoxy and Religious Rights in Medieval Islam: A Reality Check on the Road to Religious Toleration, in id., at 53.

22. See generally Bat Yeor, Islam and Dhimmitude: Where Civilizations Collide (Miriam Kochan and David Littman trans., Fairleigh Dickinson University Press 2001); but cf. COHEN, supra note 19 (having very different conclusions).

23. John Langan, Une Foi, Une Loi, Un Roi: Political Authority and Religious Freedom in the West, from Constantine to Jefferson, in JusticE AND Rights, supra note 20, at 63-71.

24. See Johnston, supra note 7.

25. For a good historical oversight of Islamic law see generally WAEL HALLAQ, A History of Islamic LEgal TheORIES: An INTRODUCTION to SunNi USUl AL-FIQH (1997).

26. Fiqh in Arabic literally means "understanding." Mohamed Arafa, President Mursi's Egypt Arab Spring: Does Egypt will Continue to be a Civil State or Under the Umbrella of Islamic (Sharie'a) Law and Islamism?, 9 US-CHINA L. REV. 6, 7 (2012) In Islamic law it refers to the applied jurisprudence of the legal scholars (fuqaha) and therefore the vast legal literature produced by the four main Sunni schools of law and the two Shi'i ones. Id.

27. See generally Wael B. Hallaq, Was the Gate of Ijtihad Closed?, 16 InT'L JournaL of Middle East Studies 3, 1 (1984). 
Muslim jurists today distinguish sharply between that juridical legacy (fiqh) and the ideals of a good, godly society, as enshrined in Islam's sacred texts $\left(\right.$ Shari'a). ${ }^{28}$ Even in its popular usage, Shari'a norms are constantly reinterpreted and reapplied in changing contexts from country to country. ${ }^{29}$

Sudanese American legal scholar Abdullahi An-Na'im provides much of the inspiration for one of the books reinterpreting Shari'a norms, since he and his colleagues at the Emory School of Law launched the Fellowship Program in Islam and Human Rights, which ran four years thanks to a grant from the Ford Foundation (2001-2005). ${ }^{30}$ The book, Islam and Human Rights: Advocacy for Social Change in Local Contexts, ${ }^{31}$ features the work of younger scholars in this field mostly from the countries where they have conducted their research: Senegal, Philippines, Indonesia, Nigeria, Malaysia, Yemen, and Morocco. ${ }^{32}$

In this book Recep Senturk, Associate Professor of Sociology at the Center for Islamic Research in Istanbul Turkey, offers an original rereading of Islamic legal history by tracing two contrasting positions on the dignity of the human person - the "universalistic view" ("basic rights accorded by virtue of being a human") 33 and the "communalistic view" ("basic rights are accorded by virtue of Islamic faith or a treaty"). ${ }^{34}$ Senturk aptly summarizes my point about how law and theology can be significantly reinterpreted in new contexts. He noted how "[g]lobal society requires universal consensus on the rules of exchange, such as reciprocity, for international trade, sports, law and politics to be possible." $" 35$ This consensus has always existed, particularly with regard to trade and sports. ${ }^{36}$ He then comes to his central argument:

28. See generally Khaled Abou El Fadl, Reasoning with God: Reclaiming SHARI'AH IN THE MODERN AgE (2014).

29. See Wael B. Hallaq, Shari’a: Theory, Practice, Transformations (2009).

30. See Islam and Human Rights: Advocacy for Social Change in Local CONTEXTS, at preface (Abdullahi Ahmed An-Na'im \& Mashood Baderin eds., 2006).

31. See generally id.

32. See Islam and Human Rights: Advocacy for Social Change in Local Contexts, $\begin{array}{lllll}\text { CENTER FOR THE STUDY OF LAW AND RELigion, } & \end{array}$ http:/cslr.law.emory.edu/publications/publication/title/islam-and-human-rights-advocacyfor-social-change-in-local-contexts/ (last visited Oct. 11, 2014, archived at, http://perma.cc/S6YT-2BSE).

33. Recep Senturk, Sociology of Rights: 'I Am Therefore I Have Rights:' Human Rights in Islam between Universalistic and Communalistic Perspectives, in ISLAM AND HuMAN Rights: Advocacy for Social Change in Local ConteXts 387-92 (Abdullahi Ahmed An-Na'im \& Mashood Baderin eds., 2006). He sees this minority current as first championed by eighth-century jurist Abu Hanifa (d. 767), eponymous founder of the Hanafi School of Law, which, perhaps not coincidently, was the school of choice within the Ottoman Empire and present day Turkey. See id.

34. Id.

35. Id. at 377 .

36. Id. 
I argue that all universal cultures, be they religious or secular, ancient or modern, commonly agree on the inviolability of all human beings. Yet they do so on their own terms, which is an inevitable outcome of social and cultural diversity. Consequently, there is not a single universalism, which is unanimously accepted by humanity as a whole, instead, there are various universalisms emanating from different cultures. . . Y Yet the points of agreement are sufficient to serve as the axioms of a global dialogue among them. ${ }^{37}$

In the next section I come back to Tesòn's discussion about cultural relativism and its seeming threat to the integrity of human rights theory and explore whether Senturk's above formulation of the problem is in any way compatible with Tesòn's concerns.

\section{CUltURAL RELATIVISM AND THE NATURE OF RightS}

One of three conclusions that Cornell draws in his essay on religious rights in Medieval Islam is that "Muslims need to devote much more time than they have so far to the study of Western moral philosophy." ${ }^{38}$ He gives an example from the work of Wesley N. Hohfeld who concluded that "P has a right to $\mathrm{X}$ " has four possible meanings, while illustrating his points with the subject of religious freedom in the Islamic past. ${ }^{39}$ The first is that of a privilege, or bare liberty, meaning the freedom to practice a strict minimum of their faith. ${ }^{40}$ Another version is that "[a] right may constitute a type of immunity from legal change." 41 Though pre-modern Islam was known for respecting minimal worship rights for populations of the ahl alkitab ("people of the book"), ${ }^{42}$ its leaders did not always follow the hadith

37. Id.

38. See generally Vincent Cornell, Religious Orthodoxy and Religious Rights in Medieval Islam: A Reality Check on the Road to Religious Toleration, in JUSTICE \& RIGHTS, supra note 20.

39. Id. at 55-56 (citing Wesley Hohfeld, Fundamental Legal Conceptions as Applied in Judicial Reasoning, 26 YALE L.J. 710 (1917)). My intention here is not to develop Hohfeld's thought in detail, as that would take us too far afield our topic. Yet it is worth pointing out that his seminal definition of "rights" in 1917 has become influential for human rights. See for example Javaid Rehman's discussion of these issues in Conflicting Values or Misplaced Interpretations? Examining the Inevitability of a Clash between 'Religions' and 'Human Rights, ' in Does God Believe in Human Rights? (Studies in Religion, Secular Beliefs AND Human Rights) 65-88 (Nazila Ghanea, Alan Stephens, Raphael Walden eds., 2007).

40. Cornell, supra note 38 , at 55.

41. Id. at 56.

42. YEOR, supra note 22. 
prescriptions to show respect to them. ${ }^{43}$ Of course, rulers mistreated whole segments of their own Muslim population, ${ }^{44}$ as did rulers in other realms, as is generally known.

A third meaning of right is "the ability or power of an individual to alter existing legal arrangements." 45 Sultans at the court of the Abbasid caliphate in Baghdad (762-1258) held the reigns of political power in a realm that was being slowly dismantled by rival kingdoms and petty dynasties at the edges of the empire. ${ }^{46}$ Yet when it came to the treatment of minorities from a legal standpoint, it was only the ulama (the class of Islamic scholars and jurists) who had the power to change those "religious" laws. Cornell offers some examples of different positions taken by some of these ulama. $^{47}$

The fourth meaning is the one most in use today with regard to the philosophy of human rights and it would have raised the bar for Muslim rulers in their responsibility toward minority religious groups: "a claimright" would impose a duty on a sultan to allow Jews and Christians to worship "as they please." 48 Legal philosophers distinguish two types of claim-rights, those in personam and those in rem. ${ }^{49}$ Here is Cornell's explanation:

Claim-rights in personam are duties that are assignable to particular persons because of a stipulated right, such as the duties incumbent on a signatory to a contract. A treaty or compact that allows Christian subjects of an Islamic state to build churches or sell pork in their own butcher shops is an example of a claim-right in personam. Claim-rights in rem are duties that are incumbent in principle to everyone. Religious freedom as a claim-right in rem would mean that an Islamic state would have an obligation to actively assist Christians or Jews in the practice of their religion. This might include providing state funds for the construction of churches or synagogues or the prosecution of Muslim subjects for desecrating Christian or Jewish places of worship. In Western societies, violations of claim-rights are

43. Cornell, supra note 38, at 57.

44. See generally Khaled Abou El Fadl, Rebellion and Violence in Islamic Law (2006).

45. Cornell, supra note 38, at 56.

46. See Ira M. Lapidus, A History of Islamic Societies 103-111 (2nd ed. Cambridge University Press 2002).

47. Cornell, supra note 38 , at 57-59.

48. Id. at 55 .

49. Id. 
often punishable by law in this way. ${ }^{50}$

However technical these distinctions seem to be, Cornell believes that this is the kind of detail that is needed in discussions taking place nowadays with regard to religious freedom, a human right, after all, stipulated in the Universal Declaration of Human Rights and later covenants. ${ }^{51}$ From the application of apostasy laws in several Muslim countries ${ }^{52}$ to the virtual lack of any religious freedom in Saudi Arabia, ${ }^{53}$ there are no doubt plenty of case studies to tackle.

This is also the point that Malcolm Evans, an international lawyer and professor at the University of Bristol School of Law, puts across. For him, "human rights law is developing in a fashion that is likely to hinder rather than assist the realization of the goals of tolerance and religious pluralism." ${ }^{, 54}$ The main reason is that its bias toward "neutrality" actually stifles religious sensibilities, and in the case of the European Court of Human Rights it was the Muslim community that felt the most suppressed. $^{55}$

Without delving into the details, the European Court of Human Rights did adjudicate a case involving an Islamist party in Turkey against the state of Turkey in 2003. ${ }^{56}$ It declared in its judgment that "Shari'a is incompatible with the fundamental principles of democracy." ${ }^{, 57}$ Specifically, "a regime based on Shari'a, which clearly diverges from Convention values, particularly with regard to its criminal law and criminal procedure, its rules on the legal status of women, and the way it intervenes in all spheres of private and public life in accordance with religious precepts." ${ }^{, 58}$

As I said earlier, this would be according to a traditionalist and here specifically an Islamist (i.e., part of the wider "political Islam" movement) interpretation of classical Islamic jurisprudence. The court here seems to believe that Shari'a is a reified, unchangeable concept that by definition stands against all the principles and values that Europeans hold dear. The reality is that, like many Muslims as well, the court is confusing Shari'a (or

50. Id.

51. Universal Declaration of Human Rights, art. 18, G.A. Res. 217 (III) A, U.N. Doc. A/RES/217(III) (Dec. 10, 1948).

52. See Laws Criminalizing Apostasy, LiBrARY OF CONGRESS (Sept. 16, 2014), archived at http://perma.cc/B8XQ-32XA.

53. See Religious Freedom in Saudi Arabia, Berkley Center for Religion, Peace AND WORLD AFFAIRS, http://berkleycenter.georgetown.edu/essays/religious-freedom-insaudi-arabia (last visited Oct. 12, 2014, archived at http://perma.cc/3KVF-WMZG).

54. Malcolm Evans, Human Rights and the Freedom of Religion, in JustiCE \& RigHTS, supra note 20, at 109 .

55. Id. at 113-115.

56. Id. (citing Refah Partisi v. Turkey, 2003-II Eur. Ct. H.R. 267).

57. $I d$.

58. Id. 
the realization of the best possible world through obedience to God's teachings in the Qur'an and Sunna) with the actual interpretation of those ethical values and norms woven together in one of six historical packages (figh, or the applied jurisprudence of the four main Sunni schools of law and the two Shi'i schools). The field of Islamic law is hotly debated by a variety of actors in several currents today, and though most traditional stakeholders remain quite conservative, many other voices are arising both from within Muslim communities and influential Muslim scholars in university settings who argue for some fundamental changes. ${ }^{59}$

This European Court decision represents a shift, argues Evans, and it took place after the integration of much of Eastern Europe into the EU. ${ }^{60}$ It is true, he avers, that human rights are "a methodology for addressing the tensions that arise within the governance of a society." ${ }^{1}$ This involves "policing the boundaries between the public and private sphere." ${ }^{162}$ On the other hand, as he examined a variety of cases handled by the court, he came to the conclusion that increasingly "ensuring respect" meant not so much "respect by others for religion" but "respect by religions for others." ${ }^{63}$ This was plainly what was happening in its very first case, which led to a Jehovah's Witness member being slapped with criminal charges for proselytism. $^{64}$

I certainly understand Evans' concerns as a lawyer but I take issue with him when he writes that "the international human rights instruments" do not constitute "an ethical code." ${ }^{65}$ True, the application of these instruments must be implemented within the best possible legal framework so that justice is maximized; in that sense it is strictly about law. He likely would have agreed with the point Cornell made that contemporary legal theory was necessary for Muslims (and others) to ponder and, all the more,

59. With regard to human rights and the range of Muslim positions, see generally David L. Johnston, supra note 5. UCLA's scholar of Islamic law Khaled Abou El Fadl's recent book REASONING WITH GOD, supra note 28 , is the best summary of the debates taking shape at this time. Two other influential works by scholars teaching in the United States are Abdullahi Ahmed An-Na'im, Islam and the Secular State: Negotiating the Future of Shari'a (2008), and Abdulaziz Sachedina, Islam and the Challenge of Human Rights (2009). Tariq Ramadan is a very influential European Muslim scholar at Oxford University and he serves as a counselor to the European Commission on Muslim affairs. See for instance these two recent books of his: RADICAL REFORM: ISLAMIC ETHICS AND Liberation (2008), and The Quest for Meaning: Developing a Philosophy of PluRALISM (2012).

60. Evans, supra note 54, at 113.

61. Id. at 109 .

62. Id.

63. Id. at 113

64. Id. at 112. Admittedly, there is a clash of values that in Europe's multicultural society is inevitable and the state has the duty to arbitrate. But the problem is that the law is tilted toward the secular claimant. Id.

65. Id. at 109-110. 
how this theory is implemented in practice in societies that are increasingly pluralistic. ${ }^{66}$ But just as I contended earlier that theology and law in the case of human rights are intermingled, so are moral philosophy and ethics.

This brings me back to Tesòn's wrestling with cultural relativism, the view according to which "local cultural traditions (including religious, political, and legal practices) properly determine the existence and scope of civil and political rights enjoyed by individuals in a given society." ${ }^{.67}$ The logical implication from such a view is that a human rights violation in one context could be considered lawful elsewhere and, in any case, Western ideas of human rights should never be imposed on other countries. ${ }^{68}$ As Tesòn puts it, "Tolerance and respect for self-determination preclude crosscultural normative judgments. ${ }^{\prime 69}$ Here we are plainly dealing with ethical issues arising out of the work of social scientists, and likely also out of a sense of guilt for past colonial sins. Indeed, international law is obliged "to respect the cultural identities of peoples, their local traditions, and customs." ${ }^{, 70}$ At the same time, adds Tesòn, respect for cultural differences in no way rules out a "substantive core" in international human rights law. ${ }^{71}$

The core of the human rights paradigm can easily be gleaned from a number of international human rights treaties, as well as the practice of international diplomacy, which by definition is cross-cultural. As Tesòn sees it, these treaties "offer a surprisingly uniform articulation of human rights law." The following rights elaborated in such treaties "should have essentially the same meaning regardless of local traditions:" the rights "to life, to physical integrity, to a fair trial, freedom of expression, freedom of thought and religion, freedom of association, and the prohibition against discrimination," etc. ${ }^{72}$

But on his way to refute the position of cultural relativism (at least as a tool to dismantle the integrity and validity of human rights norms), Tesòn declares (contra Malcolm Evans) that "the statesmen who drafted the UN Charter were motivated in part by the moral imperative to restore human dignity and give it legal status. ${ }^{, 73}$ That is why the human rights discourse is

66. Cornell, supra note 38 , at 60-61.

67. Teson, supra note 6 , at 379 .

68. An example of this would be to forgo any criticism of Female Genital Mutilation (FGM), also known as female circumcision. This covers a spectrum of practices traditionally found on the African continent and elsewhere. See Female Genital Mutilation, WorLd HeAlth Organization (Feb. 2014), archived at http://perma.cc/B7Y7-G4FR.

69. Teson, supra note 6, at 380.

70. Id. at 382 (giving an example of Westerners not having the right to enjoy Western judicial procedures when living outside their own context: "Arbitral tribunals have consistently refused to accept the claim that partially nonadversary criminal procedures violate the international minimum standard concerning the right to a fair trial.”).

71. Id.

72. Id.

73. Id. 
itself borrowed from moral philosophy. And despite the many other concerns the United Nations has had to confront over the years-most of them related to issues of national sovereignty and resolving conflictshuman rights law has continued to grow rapidly. Part of this is because moral philosophy remains at the heart of the human rights enterprise. Though some countries with dubious human rights records cannot sometimes be convicted for contravening positive international rules, the world condemns human rights violations as egregious moral wrongs and thereby puts pressure on international leaders to at least censure them, if not force them to change. ${ }^{74}$

At this point Tesòn turns his attention to cultural relativism, which comes in three types. The first is "descriptive," simply stating that, in fact, societies catalog right and wrong differently. ${ }^{75}$ Tesòn admits that this can be the case, but this type is not his main concern. He would even be willing to concede it for the sake of his argument. ${ }^{76}$ The second type, "metaethical" relativism, is a philosophical assertion about ethical values - they either do not exist, or they cannot be meaningfully grasped or demonstrated. ${ }^{77}$ "Normative" relativism is the third type. It is neither on the level of an anthropologist describing the moral values by which a particular society lives, nor is it on the level of ethical theory, as is metaethical relativism. ${ }^{78}$ Rather, normative relativism operates on a more practical moral plane by asserting that people in various cultural contexts ought to follow the ethical norms of their society. ${ }^{79}$

Tesòn first shows how the metaethical relativist can still function in the world without having an infallible method for proving moral truth, ${ }^{80}$ but he devotes more space to refuting the normative relativist position. ${ }^{81}$ In the first place, it is incoherent: on the one hand it asserts that there are no universal moral principles, and on the other, it states that one always ought to follow the moral principles of one's society - a universal moral statement. ${ }^{82}$ Secondly, moral discourse aims at universalizability. ${ }^{83}$ After making several points contrasting the normative relativist position and the

74. Id. at 383. The classic example is the Apartheid regime in South Africa and the successful international pressure exerted on its government in the name of human rights in the 1970 s and 1980 s.

75. Id.

76. $I d$.

77. Id. at 383-384.

78. Id. at 384 .

79. Id.

80. Id. The author turns to John Rawls' notion of "reflective equilibrium" which allows one to reach moral conclusions "by checking one's moral intuitions against one's moral principles with the crucial proviso that both be subject to modification." Id. at 384 .

81. See id. 385-389.

82. Id. at 385 .

83. Id. at 388 . 
logic of moral theory, Tesòn concludes that one's particular ethnic or cultural context is not morally relevant to one's having the same basic rights as all other human beings. ${ }^{84}$ In his words, "This principle of moral worth forbids the imposition upon individuals of cultural standards that impair human rights." ${ }^{85}$ Why such a conservative stance, asks Tesòn? Just because that society's authorities expect people to submit to cruel and demeaning treatment does not make it morally right. ${ }^{86}$ In fact we come back to the beginning of this paper: human rights discourse asserts that all people's worth qua human beings are entitled to basic and inalienable rights.

I began this section asking whether Recep Senturk's assertion that there were "several universalisms" and yet enough common moral ground "to serve as the axioms of a global dialogue" among its various cultures was still compatible with the universality of the human rights paradigm. I think that it is. As much as I agree with Tesón's refutation of cultural relativism, I do not think that he would strongly disagree with Senturk's assertion. He would probably ask him to define that "core" more specifically and would probably chide Senturk for his use of the plural "universalisms." But this points to the complexity of human rights discourse. While Evans sees it as a strictly legal instrument, Tesón considers it primarily a moral philosophy, at least in its roots and universal appeal. Senturk, for his part, looks at the many disagreements among Muslims themselves about how to reinterpret their millennium-long tradition of religious jurisprudence, and suggests that it would be prudent to include different approaches to human rights, while of course holding fast to the universal primacy of human dignity.

All of this underscores the multifaceted nature of "human rights" as a concept. Another angle from which to grasp this complexity is provided by Heather Widdows in her book, Global Ethics: An Introduction. ${ }^{87}$ Professor of Global Ethics at the University of Birmingham's Department of Philosophy, ${ }^{88}$ Widdows explains how this relatively new field of study draws from an array of disciplines - philosophy, politics, public policy, law, theology, international development, and sociology. ${ }^{89}$ The issues global ethics explores range from "the 'war on terror,' rogue states, child labour, torture, scarce resources, trafficking, migration, climate change, global trade, medical tourism, global pandemics, humanitarian intervention and so

84. Id.

85. Id.

86. Id.

87. Heather Widdows, Global Ethics: An Introduction (2011).

88. Professor Heather Widdows-Department of Philosophy, Univ. OF BIRMINGHAM, http://www.birmingham.ac.uk/staff/profiles/philosophy/widdows-heather.aspx (last visited Apr. 13, 2014, archived at http://perma.cc/7UBF-QBAM).

89. WidDOWs, supra note 87 , at 1 . 
on. ${ }^{990}$ Her introduction to the field is thus organized around what she calls the global ethicist's "tool box:" case studies, moral theory, political theory, rights theory, global governance, global poverty, global conflict, bioethics, climate ethics, and gender justice. ${ }^{91}$ Notice how "human rights" theory forms one of three major theoretical frameworks, which, in a complementary way, illuminate and guide the task of thinking ethically about our shrinking world's challenges.

The very fact that human rights are widely recognized as valid and important instruments make them "the most obvious candidate to be considered a global ethic in the current system of global governance." 92 Global ethics, as she has argued in preceding chapters, "requires some kind of universalist approach and human rights offer a means to assert universal respect for all human beings simply on the grounds that they are human." She then evaluates which among the competing moral theories are best suited to support human rights theory. ${ }^{94}$ Further on in this chapter on rights she notes that "it is important to recognize that human rights as established in the current global system are not always directly equivalent to rights as understood in philosophical theories." ${ }^{\text {95 }}$ Her explanation leads us back to our prior discussion using Tesón and Evans as interlocutors. International law is just that-legal documents meant to be debated and adjudicated in international courts as specific cases arise: "While philosophical works do, of course, feed into how human rights are regarded, particularly with regard to how they are established and justified, how they work in practice is largely a matter of law and governance mechanisms." 96

My last point in this paper, however, is a good example of a whole area of human rights that does not fall under the purview of international law: economic rights, as they are laid out in the 1966 International Covenant on Economic, Social, and Cultural Rights. Here, more than in any other area, theology and moral theory come together to provide, if not a road map, then at least a strong incentive to reduce the glaring economic inequalities in our world.

\section{A Muslim-Christian DeCLARATION Of Social Justice}

Widdows is particularly helpful in introducing theoretical concerns we will need to for considering economic rights. The first distinction she

\footnotetext{
90. Id.

91. Id. at 2.

92. Id. at 98 .

93. Id.

94. Id. at 99.

95. Id. at 104 .

96. $I d$.
} 
makes is between three "generations" of rights. ${ }^{97}$ This is well known and simply reflects the historical development of human rights since the UDHR. The first generation dealt with civil and political rights; the second with economic and social rights; and the third with group rights, like the Declaration of Principles of Indigenous Peoples (1989). ${ }^{98}$ This is an important concept because it explains why the above 1966 covenant has lacked the backing of several nations, the United States in particular. ${ }^{99}$ The American perception is that this is a more collectivist, if not socialist, conception of human rights. Though that may be an exaggeration, it nevertheless runs against the American (and Western, generally) cultural priority on freedom and individual rights - certainly in evidence in the Declaration of Independence.

A second distinction Widdows makes also touches on the individual versus community idea: "negative" versus "positive" rights. A negative right only stipulates that one be left alone in the exercise of one's rights. ${ }^{100}$ No one has the right to interfere in another person's peaceful enjoyment of his or her freedom. A positive right, by contrast, requires people to act, for instance a police force to patrol my neighborhood in light of my positive right to protection from harm. ${ }^{101}$ Then too, as stated in the UDHR, since everyone has the right to work and "the right to a standard of living adequate for the health and well-being of himself and of his family" (article 23 ), either the state or the international community, if the state coffers are too depleted, should step in and help meet these needs. ${ }^{102}$ Naturally, this is not only controversial on a theoretical level, it is also very difficult to achieve in practice, mostly for political reasons.

This brings us to the last distinction Widdows makes, between "basic" and "secondary" rights. ${ }^{103}$ This concept was first popularized by the

97. Id.

98. This third generation of rights, from the late 1980s on, continued with, for instance, a Draft Declaration on the Rights of Indigenous Peoples, see United Nations Declaration on the Rights of Indigenous Peoples, G.A. Res. 61/295, U.N. Doc. A/RES/61/295 (Sept. 13, 2007), 46 I.L.M. 1013 (2007), and a series of conventions on the environment starting with the Kyoto Protocol, see Kyoto Protocol to the United Nations Framework Convention on Climate Change, Dec. 10, 1997, U.N. Doc FCCC/CP/1997/7/Add.1, 37 I.L.M. 22 (1998), coming into force in 2005. The ongoing work of the United Nations Framework Convention on Climate Change is also premised on this idea that a healthy environment is the right of all people equally sharing the same planet, see United Nations Framework Convention on Climate Change, May 9, 1992, S. Treaty Doc No. 102-38, 1771 U.N.T.S. 107.

99. United Nations, International Covenant on Economic, Social, and Cultural Rights (Status), United Nations TReATy Collection (Oct. 12, 2014), archived at http://perma.cc/6C4J-GMPZ.

100. WIDDOWs, supra note 87, at 113 .

101. Id.

102. Universal Declaration of Human Rights, supra note 51.

103. WIDDOWs, supra note 87 , at 114 . 
work of Henry Shue. ${ }^{104}$ Shue argued that one cannot function as a human being without some minimal rights. ${ }^{105}$ Widdows summarized his position in the following table; notice where the economic rights come in:

Shue's basic rights:

-provide minimum protection against "utter helplessness;"

-protect the defenceless against devastating threats;

-function as a restraint against otherwise overwhelming economic and political forces;

-guarantee to meet some basic needs; below. ${ }^{106}$

-provide a minimal standard no one should be permitted to fall

Correspondingly, Shue posits three duties that correlate to these basic needs: "[d]uties to avoid depriving[;] [d]uties to protect from deprivation[;] [d] uties to aid the deprived." 107 Western-based reasoning, when it comes to prioritizing rights, has been eager to assign greater priority to negative rights over positive rights, and "civil and political rights over social and economic rights." 108 This makes any kind of argument to the effect that extreme world poverty represents a moral imperative. Likely because of this, Thomas Pogge, a German philosopher with simultaneous academic appointments at Yale University and the University of Oslo, ${ }^{109}$ reframes duties to the poor as negative duties. ${ }^{110}$ As Widdows puts it, "[h]e claims that to fail to help the global poor is to violate negative moral duty: a duty

104. See id.; see generally Henry Shue, Basic Rights: Subsistence, Affluence, And U.S. Foreign POLICY (1980).

105. See WidDows, supra note 87 , at 114.

106. Id. at 115 .

107. Id. at 117 (alterations added, emphasis in original).

108. Id. at 118. The two UN covenants ratified in 1966, the ICCPR and the ICESCR, represent the clear divide between negative rights (civil and political) and positive rights (economic, social and cultural). See generally ICCPR and ICESCR, supra note 1. Critics of Shue's concept of the "basic" rights (see generally SHUE, supra note 104) argue that they are indeed

very demanding . . . . In particular, they do not respect the standard forms of reasoning we have discussed above: that civil and political rights take priority over social and economic rights and that negative rights take priority over positive rights. Shue explicitly includes in his list of basic rights not only the civil and political rights of liberty and security, but also the social and economic right of subsistence.

WidDOws, supra note 87 , at 116.

109. Thomas Pogge, Director, YALE UNIVERSITY, http://www.yale.edu/macmillan/globaljustice/pogge.html (last visited Oct. 1, 2014, archived at http://perma.cc/5XBK-4CSU).

110. WIDDOWs, supra note 87, at 159. 
not to harm." "So in disregarding the poor, he argues, "we are culpable in failing our negative duty to stop bringing about the injustice."112 Poverty, therefore, is indeed the responsibility of richer nations, who in their policies of neglect have harmed the poor. ${ }^{113}$ Of course, Pogge's assumption - and he sets out to prove this - is that global poverty is in large part caused by the rich and their institutions. ${ }^{114} \mathrm{He}$ discusses the policies of the World Bank and the International Monetary Fund, the exclusion of poorer countries from the use of their natural resources, the predatory nature of multinational corporations and the adverse affect they have on the economies of developing nations; and finally the consequences of past colonialism and war. ${ }^{115}$

This is also the belief of many Muslim intellectuals and religious leaders, most likely because many of the OIC countries (the fifty-seven members of the Organization of the Islamic Cooperation) are some of the poorest countries in the world. ${ }^{116}$ In a presentation I made at an EvangelicalMuslim conference on peacebuilding, I began by quoting the spiritual father of the Lebanese Shi'ite Hezbullah, Sayyid Hasan Nasrallah. ${ }^{117}$ In a book devoted to Muslim-Christian dialogue, Nasrallah wrote that the world is split between al-mustad'afun (the downtrodden or oppressed) in the poorest countries or the poorest neighborhoods and al-mustakbirun, the world's arrogant ones, the Western powers, or the forces of "colonialism and imperialism."

111. Id.

112. Id.

113. See id.

114. Id. at 160 .

115. Id. The adjective "predatory" is my own, but based on Widdow's description of Poggue's views. Poggue

argues that world poverty comes about from an international order largely imposed and upheld by richer Western nations: from shared social institutions ... from poorer nations being excluded from the use of their natural resources (such as when Western magnates and, more recently, corporations have established themselves in foreign countries to utilize crops and minerals, not to mention cheap labour); and relatedly, from the historical effects of colonialism and war.

Id.

116. See About OIC, Organisation of Islamic Cooperation, http://www.oicoci.org/oicv2/page/?p_id=52\&p_ref=26\&lan=en (last visited Oct. 1, 2014, archived at http://perma.cc/4T8-HFJ6). Among some of its poorest members, for instance, you find Uzbekistan, Uganda, Bangladesh, Benin, Burkina-Faso, Tajikistan, Turkmenistan, Tchad, Togo, Djibouti, Senegal, Sudan, Suriname, Sierra Leone, Somalia, Mali, Egypt, Mauritania, Niger, Nigeria and Yemen. Id.

117. David L. Johnston, Rethinking Human Rights: A Challenge for Muslims and Christians, in Peace-Building By, Between, and Beyond Muslims and Evangelical Christians 215 (Mohammed Abu-Nimer and David Augsburger, eds., 2009).

118. Id. 
In my reading of contemporary Islam I have found this attitude prevalent. A very different source this time, Chandra Muzaffar, a Malaysian academic and activist and founder of JUST (International Movement for a Just World), ${ }^{119}$ has been outspoken about the global disparities in power and resources, which have only become more extreme in recent years. ${ }^{120}$ Already in 1994 he convened a conference in Kuala Lumpur with delegates hailing from over sixty countries on the theme, "Rethinking Human Rights." 121 The essays were later collected in a volume he edited himself entitled, Human Wrongs: Reflection on Western Global Dominance and Its Impact on Human Rights. ${ }^{122}$ A more recent book echoes some of these themes:

In fact, American hegemony over global politics, the global economy and global culture is viewed as one of the most formidable obstacles in humankind's quest for a just world. It is partly because of the type of unjust global system that has evolved in recent decades with the US at its helm that 1.5 billion people live on less than one dollar a day; that 3 of the world's richest men earn more than the Gross Domestic Product of the world's Least Developed Countries (LCDs); that the gap between the top 20 percent and the bottom 20 percent of the planet's population has widened from a ratio of 1:30 in 1960 to $1: 85$ in $1997 .{ }^{123}$

The last chapter in that book deals with a subject germane to this essay: "Shaping a Global Ethic: The Role of Islam and the Muslim Community." 124 Rightly so, he traces the phrase "global ethic" to the 1993 Parliament of the World's Religions. ${ }^{125}$ The final declaration, written by Catholic theologian Hans Küng, affirms that there can be "no better global order without a global ethic." 126 It also reaffirms the UN's Universal

119. See Home Page, International Movement For A Just World, http://www.justinternational.org/ (last visited Sept. 22, 2014, archived at http://perma.cc/DH43-CP73).

120. See Joseph E. STIGlitz, IneQuality Is Not InEVitAble (June 27, 2014), archived at http://perma.cc/MFJ3-2X68.

121. See Chandra Muzaffar, Human Wrongs: Reflection on Western Global DOMINANCE AND ITS IMPACT ON HumAn RightS, at Introduction (1996).

122. Id. at 85 . For more details on this conference and this book, see Johnston, supra note 117 , at 220 .

123. Chandra Muzaffar, Muslims Today: Changes Within, Challenges Without 1 (Mumtaz Ahmad ed. 2011).

124. Id. at 241-254.

125. Parliament of the World's Religions, Declaration Toward a Global Ethic (1993), archived at $\mathrm{http}: / /$ perma.cc/C9LS-4X7K.

126. A Global Ethic: The Declaration of the Parliament of the World's RELIGIONS 21 (Hans Küng and Karl-Josef Kuschel eds., 1993). 
Declaration of Human Rights, saying that

[w] hat it formally proclaimed on the level of rights we wish to confirm and deepen here from the perspective of an ethic: the full realization of the intrinsic dignity of the human person, the inalienable freedom and equality of all humans, and the necessary solidarity and interdependence of all humans with each other. ${ }^{127}$

Muzaffar builds on this global ethic common to the world's religions and explains why it specifically "resonates with Islamic teachings:"

It is because Islam is cognizant of the divisions and antagonisms generated by vast economic and social gaps between the rich and the poor that it seeks to distribute wealth in a just and equitable manner. ... Some of the most established institutions and practices of Islam - the wealth tax (zakat), the prohibition on interest or usury (riba), the bequeathal of personal estates for the public good (waqf), and the acts of charity (sedekah) - are all connected in one way or another with social justice. ${ }^{128}$

European Muslim scholar, Tariq Ramadan, ${ }^{129}$ also referred to the act of creation to underscore human solidarity and the imperative for a just global order from a Muslim perspective: "there can be no religious consciousness without a social ethic. . . . Being responsible before God for one's own person and to respect creation as a whole, one should offer to all people on the social level the means to fulfill their responsibilities and to protect their rights." $" 130$

On the Christian side, the moral imperative to alleviate the suffering of the poorest as a claim on the rich came most recently in Pope Francis' first document, technically an "apostolic declaration," entitled Evangelii Gaudium ("The Joy of the Gospel"). ${ }^{131}$ The Gospel, or literally "the good news" about Jesus Christ, ${ }^{132}$ "is about the kingdom of God (cf. $L k 4: 43$ ); it

127. Id. at 20 .

128. MuZAFFAR, supra note 121, at 245-246.

129. See sources cited, supra note 59.

130. TARiQ Ramadan, WeStern Muslims And the Future of IsLam 149 (2005).

131. Id.

132. The word evangelium in Latin (as appears in the Pope's title) comes directly from the Greek euangelion, meaning literally "good news." See Douglas Harper, Evangelist (n.), ONLINE ETYMOLOGY DICTIONARY, http://www.etymonline.com/index.php? $1=\mathrm{e} \& \mathrm{p}=27 \&$ allowed_in_frame $=0$ (last visited Oct. 12, 2014, archived at http://perma.cc/DZ7U-5CP4). 
is about loving God who reigns in our world. To the extent that he reigns within us, the life of society will be a setting for universal fraternity, justice, peace and dignity." "133 In a way reminiscent of much Islamic discourse today, ${ }^{134}$ Pope Francis contends that religion cannot be restricted to the private sphere or be exclusively about people's welfare in the hereafter. ${ }^{135}$ For this reason, "authentic faith-which is never comfortable or completely personal - always involves a deep desire to change the world, to transmit values, to leave this earth somehow better that we found it." ${ }^{136}$ Because Jesus lived in close solidarity with the poor and called his disciples to care for them as a priority, ${ }^{137}$ a Christian cannot remain oblivious to the suffering of the weak and indigent. Here is a passage that nicely sums up from a Christian perspective (yet entirely in harmony with an Islamic one as well) the moral claims the poor have on the rich [what claim-rights the poor have on the rich]:

133. Pope Francis, Apostolic Exhortation Evangeli Gaudium of the Holy Father Francis To the Bishops, Clergy, Consecrated Persons and the Lay Faithful On the Proclamation OF THE GOSPEL IN TODAY's WORLD 142 (2013), archived at http://perma.cc/6R44-GN52.

134. "Islam," Muslims believe is God's revelation to guide believers in every sphere of life, just like when Muhammad emigrated from Mecca where he and his followers were persecuted to Medina where he ruled as both prophet and statesman for ten years before his death $632 . \quad$ Muhammad, http://www.pbs.org/empires/islam/profilesmuhammed.html (last visited Oct. 12, 2014, archived at http://perma.cc/S5PD-E87T). Twentieth-century Islamic revivalism was largely a reaction against the secularization of society and the modern wedge driven between religion and the public sphere, religion and politics. See generally Mehdi Mozaffari, What is Islamism? History and Definition of a Concept, 8 TOTALITARIAN MovemENTS AND POLITICAL RELIGIONS 17, archived at http://perma.cc/7BAW-ZXHH). One major component of this revivalism was the segment that translated the Islamic faith into a modern political ideology, commonly referred to as "Islamism." Id. All of the authors referenced in note 59 push back against that ideology with a strong democratic and pluralistic perspective on society and politics. See sources cited supra note 59.

135. POPE FRANCIS, supra note 133, at 144.

136. Id. at 145 .

137. Pope Francis explains, God's heart has a special place for the poor, so much so that he himself 'became poor' (2 Cor 8:9). The entire history of our redemption is marked by the presence of the poor. Salvation came to us from the 'yes' uttered by a lowly maiden from a small town on the fringes of a great empire. The Saviour was born in a manger, in the midst of animals, like children of poor families; he was presented at the Temple along with two turtledoves, the offering made by those who could not afford a lamb (cf. Lk 2:24; Lev 5:7); he was raised in a home of ordinary workers and worked with his own hands to earn his bread. When he began to preach the Kingdom, crowds of the dispossessed followed him, illustrating his words: 'The Spirit of the Lord is upon me, because he has anointed me to preach good news to the poor.' (Lk 4:18).

Id. at 155 . 
Solidarity is a spontaneous reaction by those who recognize that the social function of property and the universal destination of goods are realities which come before private property. The private ownership of goods is justified by the need to protect and increase them, so that they can better serve the common good; for this reason, solidarity must be lived as the decision to restore to the poor what belongs to them. These convictions and habits of solidarity, when they are put into practice, open the way to other structural transformations and make them possible. Changing structures without generating new convictions and attitudes will only ensure that those same structures will become, sooner or later, corrupt, oppressive and ineffectual. ${ }^{138}$

Unlike Pogge, Pope Francis sees economic rights as positive rights, ${ }^{139}$ though I am sure he would also agree with Pogge that willful ignorance of dire poverty is to visit even more harm and suffering on the poor. ${ }^{140}$ In particular, he writes,

we also have to say 'thou shalt not' to an economy of exclusion and inequality. Such an economy kills. How can it be that it is not a news item when an elderly homeless person dies of exposure, but it is news when the stock market loses two points? This is a case of exclusion. ${ }^{141}$

This is perhaps the most fitting thought with which to conclude this essay about human rights and the intrinsic dignity of the human person created by God. All along, our various interlocutors have urged us to recognize how complex the notion of human rights really is. Emanating as it did from the horror of two World Wars, it had to take into account various ethical theories from a philosophical viewpoint. But it also needed a theological undergirding, in order for human rights to permeate people's thinking and acting in a world where violence and oppression wreak havoc on so many. After all, Muslims and Christians represent more than half of the world's population. And if the Parliament of the World's Religions is any indication, the ethical-religious imperative of human solidarity is shared to some extent by all people of faith.

In the end, however, as human rights lawyers like Fernando Tesòn and Malcolm are eager to emphasize, all the good moral theory and

138. Id. at $149-150$.

139. See WidDOWs, supra note 87 , at 159.

140. Id. at 159-160.

141. Id. at 45 . 
theology will go nowhere unless international law expands with new and more enforceable laws and the world's States commit to following them. Still, Pope Francis is wise to remind us that even with the best laws and the fairest international structures in place, tyranny will find a way to take root unless people at the grassroots live with compassion and solidarity with their neighbors. Such a holistic vision of human dignity is good to keep in mind when the notion of "economic rights" is still so far from general acceptance. 